\title{
SEKOLAH DASAR BERBASIS SENTRA DI KOTA PONTIANAK
}

\author{
Lyla Nursyahbani' ${ }^{1}$, Muhammad Nurhamsyah ${ }^{2}$, Lestari $^{3}$ \\ ${ }^{1}$ Mahasiswa, Program Studi Arsitektur, Fakultas Teknik, Universitas Tanjungpura \\ nursyahbanilyla12@gmail.com \\ ${ }^{2}$ Program Studi Arsitektur, Fakultas Teknik, Universitas Tanjungpura \\ ${ }^{3}$ Program Studi Arsitektur, Fakultas Teknik, Universitas Tanjungpura
}

Naskah diajukan pada: 9 Maret 2021

Naskah revisi akhir diterima pada: 15 Maret 2021

\begin{abstract}
Abstrak
Anak merupakan penerus masa depan bangsa, sehingga tumbuh kembangnya wajib dimaksimalkan terutama pada anak dalam fase childhood. Oleh sebab itu, diharapkan semua pihak dapat mendukung terwujudnya lingkungan yang baik dan ramah anak demi perkembangan mereka. Indonesia sendiri memiliki target agar seluruh wilayah di Indonesia dapat menjadi Kota/Kabupaten Layak Anak (KLA) pada tahun 2030. Salah satu indikator KLA yaitu Sekolah Ramah Anak (SRA), yang diwujudkan dalam pelaksanaan proses pembelajaran yang ramah anak. Sekolah harus bisa menggunakan pendekatan pembelajaran yang tepat untuk perkembangan anak secara optimal. Salah satu metode yang dinilai sesuai dengan tahap perkembangan anak adalah metode Beyond Centers and Circle Time (BCCT) yang di Indonesia dikenal sebagai senling atau kependekan dari sentra dan lingkaran. Pendekatan pembelajaran metode sentra adalah pembelajaran yang diaplikasikan berdasarkan area tertentu dan berpusat pada anak sebagai peserta didik. Metode sentra ditujukan untuk mengembangkan seluruh aspek kecerdasan majemuk anak usia dini melalui bermain yang terarah secara moving class. Tujuan yang ingin dicapai ialah untuk mengetahui bagaimana perancangan Sekolah Dasar berbasis sentra dengan menggunakan metode dari J.C. Jones. Konsep ruang dirumuskan dengan penerapan tekstur, warna, flexible spaces serta individual spaces yang dapat mendukung perkembangan anak.
\end{abstract}

Kata-kata Kunci: Sekolah Dasar, Metode Sentra, Anak

\begin{abstract}
Children are the future successors of the nation, so their growth and development must be maximized, especially for children in the childhood phase. Therefore, it is hoped that all parties can support the creation of a good and childfriendly environment for their development. Indonesia has a target for all regions to become a Child Friendly City/ District (KLA) by 2030. One of the KLA indicators is Child Friendly Schools (SRA), which is manifested in the implementation of a child-friendly learning process. Schools must be able to use the right learning approach for optimal child development. One method that is considered appropriate for the child's development stage is the Beyond Centers and Circle Time (BCCT) method, which in Indonesia is known as senling or short for centers and circles. The BCCT method is a learning method that is applied based on certain areas and is centered on children as learners. This method aim is to develop all aspects of multiple intelligence in early childhood through directed play by moving classes. The purpose of this is to find out how to design a BCCT based primary school using design method by J.C. Jones. The concept of space is formulated by applying textures, colors, flexible spaces and individual spaces that can support children's development.
\end{abstract}

Keywords: Elementary School, BCCT Method, Children

\section{Pendahuluan}

Anak merupakan penerus masa depan bangsa, sehingga tumbuh kembangnya wajib dimaksimalkan. Berdasarkan penelitian dari Dr. Benjamin S. Bloom, seorang professor di University 
of Chicago dapat diketahui bahwa tingkat kecerdasan anak mencapai 50\% pada usia 4 tahun, $80 \%$ di usia 8 tahun dan sisanya pada usia selanjutnya diperoleh 20\% (Direktorat Pembinaan Pendidikan Anak Usia Dini, 2011).

Disebabkan oleh pentingnya peran anak untuk bangsa, maka diharapkan semua pihak dapat mendukung terwujudnya lingkungan yang baik dan ramah anak demi perkembangan mereka. Target Indonesia pada tahun 2030 mendatang, diharapkan seluruh wilayah dapat menjadi Kota/Kabupaten Layak Anak (KLA). Salah satu indikator KLA adalah Sekolah Ramah Anak (SRA) dengan salah satu komponennya yang tertulis pada buku Panduan Sekolah Ramah Anak yaitu pelaksanaan proses pembelajaran yang ramah anak. Maka, dapat diketahui bahwa sekolah sudah seharusnya menerapkan metode belajar yang benar untuk perkembangan anak secara optimal. Salah satu metode yang dinilai tepat untuk tahap perkembangan anak yaitu metode Beyond Centers and Circle Time (BCCT). Metode tersebut dikembangkan oleh Pamela C. Phelps, Ph.D., seorang pendidik yang sudah lebih dari 40 tahun mendalami pendidikan anak usia dini. Metode yang di Indonesia dinamai metode senling atau singkatan dari sentra dan lingkaran ini ialah perkembangan dari beberapa metode yang telah ada yaitu metode Montessori, High Scope dan Reggio Emilio (Hanafi, 2014).

Di Pontianak sudah ada TK yang menerapkan sentra, namun belum ditemukan SD yang menerapkan metode ini. Beberapa daerah lain di Indonesia sudah terdapat SD yang menerapkan metode sentra, diantaranya Sekolah Dasar (SD) Batutis Al-Ilmi Bekasi dan SD Baitul Maal Banten, dimana kegiatan belajar mengajar dilakukan dengan sistem moving class dimana siswa berpindahpindah kelas sesuai dengan mata pelajaran. Manfaat dari perancangan ialah untuk mengetahui bagaimana pemecahan dari permasalahan dimana bangunan harus dirancang agar nyaman dan dapat mendukung sistem ini. Ruang kelas di sistem ini disesuaikan dengan setiap mata pelajaran. Furnitur yang dipakai disesuaikan rancangannya dengan proporsi badan anak serta dengan material yang tidak membahayakan anak.

\section{Kajian Pustaka}

Menurut Nurihsan (2007), anak usia dini adalah anak yang berusia nol tahun atau sejak lahir sampai berusia kurang lebih delapan tahun (0-8). Pendapat lainnya dari NAEYC (National Association for The Education of Young Children) mengutarakan anak usia dini sebagai anak pada rentang usia 0-8 tahun, yang tergolong dalam program pendidikan di taman penitipan anak, penitipan anak pada keluarga (family child care home), pendidikan prasekolah baik swasta ataupun negeri, TK, dan SD (NAEYC, 1992). Sedangkan menurut Sugiyanto dan Sudjarwo (1991) dalam Sumantri (2005) fase Childhood (anak-anak), ialah fase perkembangan mulai umur 1 atau 2 tahun sampai 1012 tahun, yang kemudian dikategorikan menjadi dua, yaitu early childhood (anak kecil) antara 1-6 tahun, dan later childhood (anak besar) antara 6-12 tahun.

Sekolah Dasar ialah jenjang paling dasar pendidikan formal di Indonesia, ditempuh selama enam tahun, dimulai dari kelas satu hingga kelas enam dan merupakan suatu lembaga dengan organisasi yang tersusun rapi dan segala aktivitasnya direncanakan dengan sengaja yang disebut kurikulum (Ahmadi, 2001). Sebagai lembaga pendidikan formal, sekolah yang lahir dan berkembang secara efektif dan efisien dari dan oleh serta untuk masyarakat adalah perangkat yang memiliki kewajiban untuk memberi pelayanan kepada masyarakat dalam mendidik warga negara. Sekolah dikelola secara formal, hierarkis dan kronologis yang berpegangan pada falsafah dan tujuan pendidikan nasional (Purwoko, 2001).

Sekolah Ramah Anak berdasarkan panduannya dijabarkan sebagai program untuk mewujudkan kondisi aman, bersih, sehat, peduli, dan berbudaya lingkungan hidup, yang mampu menjamin pemenuhan hak dan perlindungan anak dari kekerasan, diskriminasi, dan perlakuan salah lainnya, selama anak berada di satuan pendidikan, serta mendukung partisipasi anak terutama dalam perencanaan, kebijakan, pembelajaran dan pengawasan. Sekolah Ramah Anak adalah satu dari beberapa indikator pengembangan Kabupaten/Kota Layak Anak. 
Metode BCCT atau Senling ini sendiri dikembangkan dari beberapa metode yang sudah ada sebelumnya yaitu Montessori, High scope dan Reggio Emilio (Noorlaila, 2010). Tujuan metode ini yaitu pertama, Menstimulasi seluruh aspek kecerdasan anak (multiple Inteligences) dengan bermain secara terarah. Metode ini ditujukan untuk menstimulasi seluruh aspek kecerdasan anak untuk mengoptimalkan perkembangan kecerdasannya, sehingga otak anak perlu dirangsang agar terus berfikir secara aktif melalui pengalamannya sendiri (tidak hanya sebatas mencontoh atau menghafal). Metode ini memandang bermain sebagai wahana yang paling tepat dan satu-satunya wahana pembelajaran anak, karena selain menyenangkan, bermain dalam setting pembelajaran bisa menjadi wadah anak berfikir aktif dan kreatif. Kedua, Menciptakan setting pembelajaran yang menstimulasi anak agar saling aktif, kreatif, dan selalu berpikir melalui pengalamannya sendiri (tidak hanya menuruti perintah, meniru ataupun menghapal). Ketiga, Menggunakan standar operasional yang baku, yang berpusat di sentra-sentra kegiatan dan saat anak berada dalam lingkaran bersama guru, sehingga lebih mudah diikuti terutama untuk para pemula (Hanafi, 2014).

Menurut Depdiknas, Moving Class adalah kelas bergerak yang disesuaikan berdasarkan mata pelajaran. Konsep kelas berpindah ini pada prinsipnya untuk memudahkan siswa dalam memahami materi yang akan dipelajari karena kelas sudah difasilitasi dengan media atau sumber lain yang dibutuhkan sehingga pengajar dimudahkan dalam menata ruang ataupun menata media pembelajarannya layaknya sebuah laboratorium dimana pada kelas sudah lengkap tersedia modelmodel pembelajaran sehingga pengajar tidak perlu mencari media pembelajaran yang akan digunakan (Supriyanto, 2014).

\section{Metode}

Objek dalam perancangan adalah sekolah dasar yang berbasis dari metode pembelajaran sentra. Ruang kelas dibagi menjadi beberapa sentra dengan sistem moving class. Pengumpulan data primer diperoleh dengan survey dan wawancara. Data sekunder seperti data dari intansi pemerintahan mengenai lokasi dan peraturan serta data dari literatur yang berkaitan dengan tinjauan teori. Datadata yang telah didapatkan akan dianalisis. Adapun analisis tersebut terbagi menjadi analisis fungsi, pelaku dan kegiatan, analisis program ruang, analisis tapak, analisis bentuk dan gubahan serta analisis teknis bangunan. Metode perancangan menggunakan metode dari J.C. Jones, yang terdiri dari tahap gagasan, informasi, analisis, sintesis, evaluasi dan optimisasi (Nuraini, 2010).

\section{Hasil dan Pembahasan}

\section{Pemilihan Lokasi}

Lokasi tapak dipilih berdasarkan Peraturan Menteri Pendidikan Nasional No. 24 Tahun 2007, beberapa kriteria yaitu 1) Lahan memenuhi ketentuan luas minimum $1240 \mathrm{~m}^{2}$ untuk bangunan dua lantai, 2) Lahan terlindungi dari hal-hal yang membahayakan anak dan mempunyai akses penyelamatan darurat, 3) Lahan cocok dengan Rencana Tata Ruang Wilayah Kabupaten/Kota, 4) Lahan mempunyai status hak atas tanah serta beberapa kriteria lain yang dipertimbangkan yaitu 1) Kemudahan dan keamanan pencapaian baik dengan berjalan kaki maupun kendaraan, 2) Sasaran konsumen untuk masyarakat menengah keatas dan 3) Jarak lokasi perancangan dengan SD yang sudah terbangun minimal $1 \mathrm{~km}$.

Berdasarkan kriteria tersebut dipilih lokasi di Jl. Purnama, Kec. Pontianak Selatan yang memiliki luas $9000 \mathrm{~m}^{2}$. Lokasi dipilih karena 1) Berada di wilayah Pontianak Selatan yang merupakan daerah prima dengan pertumbuhan ekonomi yang tinggi, 2) Dekat dengan pusat kota, 3) Berada di jalan aspal dengan lebar $10 \mathrm{~m}$, 4) Jarak lokasi dengan SD terbangun lebih dari $1 \mathrm{~km}$. 

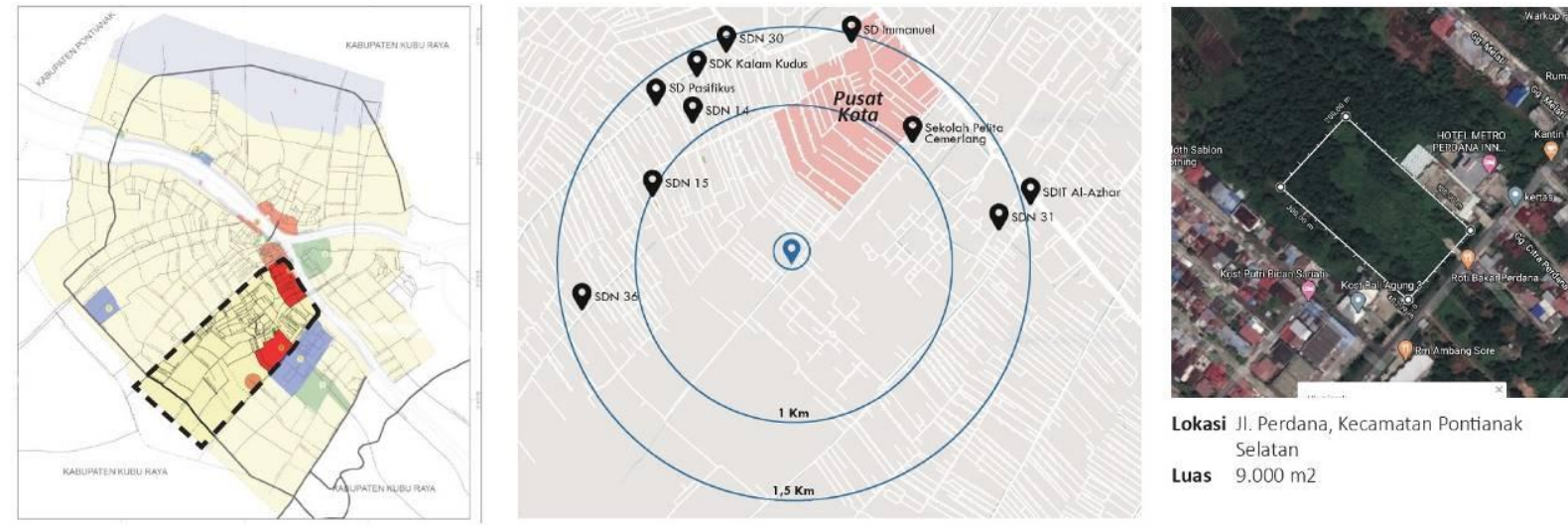

Lokasi JI. Perdana, Kecamatan Pontianak Luas $9.000 \mathrm{~m} 2$

Gambar 1. Lokasi Terpilih

Sumber: Penulis, 2020

\section{Internal}

Fungsi bangunan adalah tempat pendidikan formal yang menggunakan metode pembelajaran sentra dimana sistem yang digunakan adalah moving class. Sekolah memiliki 6 tingkat dengan 2 rombongan belajar per tingkat dan 12 siswa per rombongan. Fungsi utama yaitu untuk pendidikan dimana terdapat 6 jenis ruang sentra (sentra bahasa, sentra matematika, sentra sains, sentra seni, sentra main peran dan sentra agama). Bangunan juga memiliki fungsi pendukung berupa fasilitas untuk mewadahi kegiatan pengurus sekolah dan fungsi penunjang yang berisikan area seperti aula, kantin, koperasi dan sebagainya.

Berdasarkan Physical and Architectural Learning Environments oleh Center for Citizenship Education Foundation, ruang kelas sentra dibuat fleksibel untuk kegiatan belajar individu maupun kelompok, memiliki akses yang mudah ke ruang terbuka serta harus dapat diakses untuk semua siswa termasuk yang memiliki keterbatasan fisik. Selain itu, ruang harus memiliki bukaan yang optimal untuk penggunaan cahaya yang optimal serta memungkinkan siswa untuk terkoneksi baik terhadap lingkungan sekitarnya. Pada ruang sentra terdapat individual space pada bagian belakang untuk siswa belajar sambil bermain dengan interactive wall. Warna yang digunakan adalah warna cerah atau warna natural dari material yang digunakan. Taman dan lapangan berada di tengah, dengan area duduk di sekelilingnya serta terdapat walk path dengan kombinasi tekstur keras dan lembut untuk menstimulasi perkembangan anak.

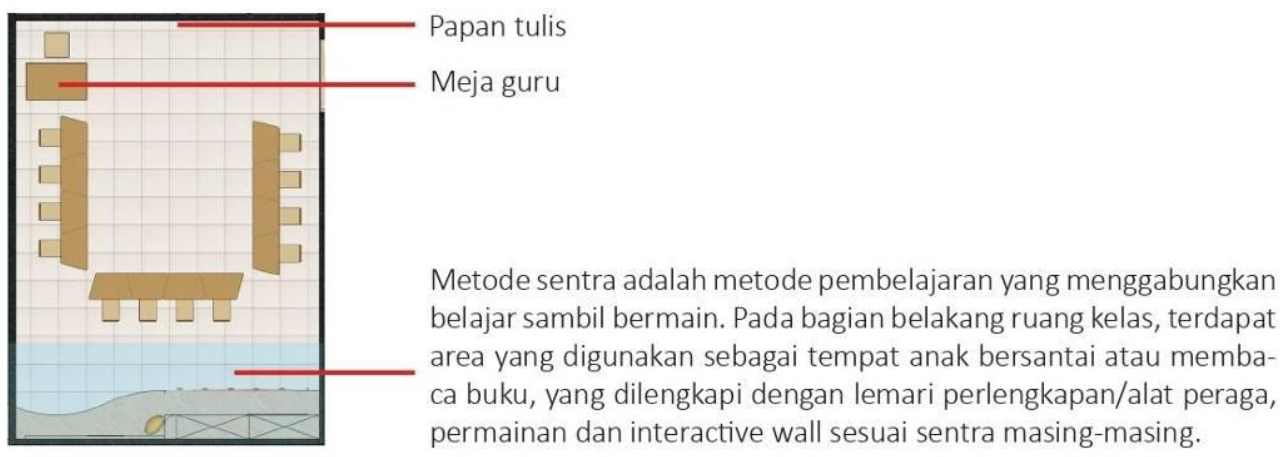

Gambar 2. Layout Ruang Sentra

Sumber: Penulis, 2020 
Pelaku dikategorikan menjadi 3 berdasarkan fungsi yaitu 1) Pelaku fungsi pendidikan yaitu guru dan siswa, 2) Pelaku fungsi pendukung yaitu kepala sekolah beserta wakil, tenaga administrasi, konselor, tenaga perpustakaan, tenaga Kesehatan dan petugas layanan khusus, 3) Pelaku fungsi penunjang yaitu staf koperasi, staf kantin dan tamu. Kegiatan pelaku dianalisis untuk mengetahui kebutuhan ruang, yang kemudian dianalisis lebih lanjut untuk mendapatkan hubungan ruang dan organisasi ruang.

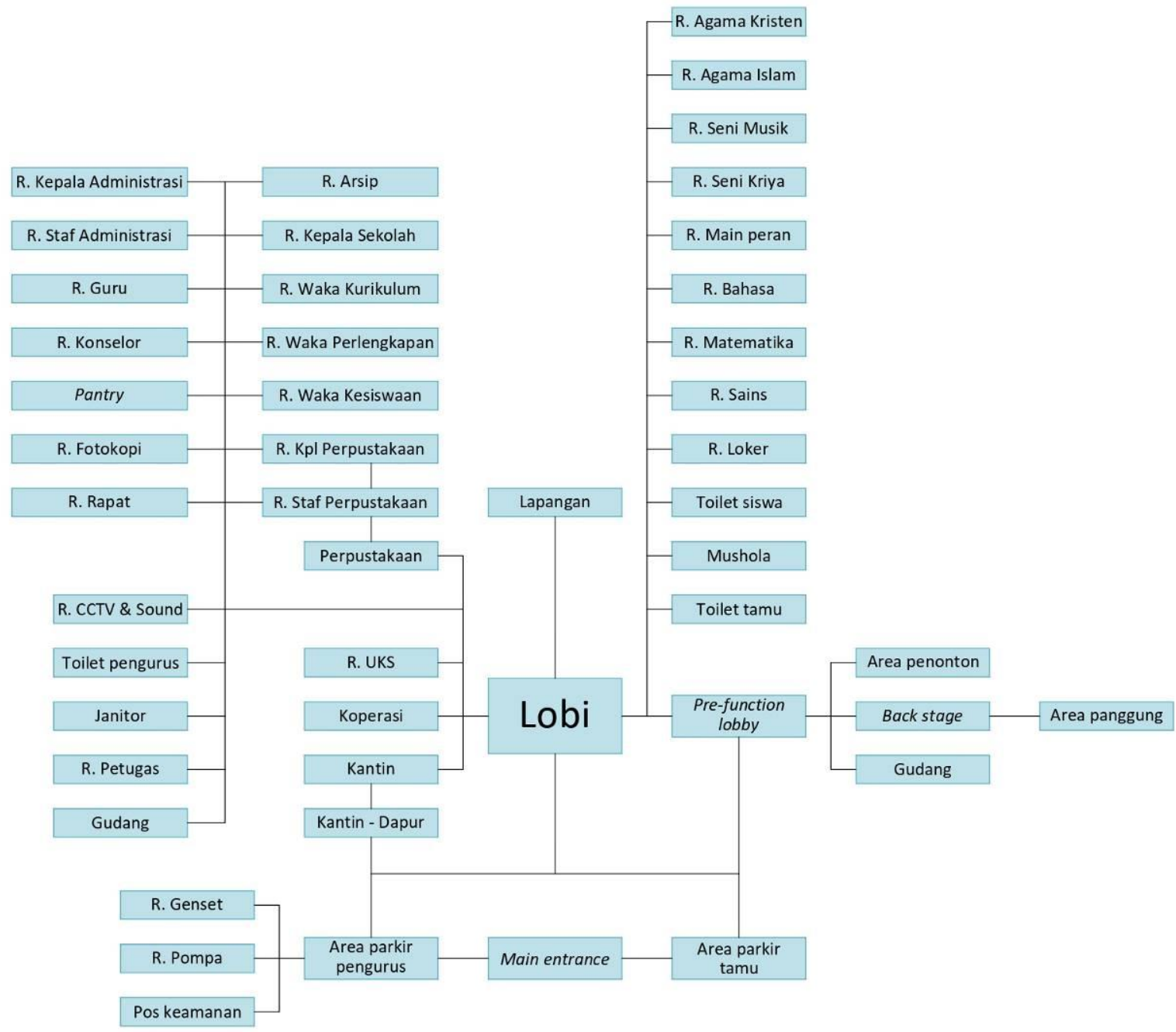

Gambar 3. Organisasi Ruang

Sumber: Penulis, 2020

\section{Eksternal}

Tapak dianalisis untuk mendapatkan peletakan, orientasi, sirkulasi, zonasi dan vegetasi bangunan. Peletakan bangunan mempertimbangkan Garis Sempadan Sungai (GSS) sebesar 15 meter, sirkulasi dan kebisingan. Hasilnya bangunan dimundurkan ke arah belakang sesuai GSS, serta untuk menghindari kebisingan dari jalanan dan untuk sirkulasi kendaraan pada bagian depan bangunan. Orientasi bangunan mempertimbangkan aspek sirkulasi dan panca indera visual. Orientasi menghadap depan (ke arah jalanan) dimana pada bagian itulah yang menjadi wajah bangunan. 


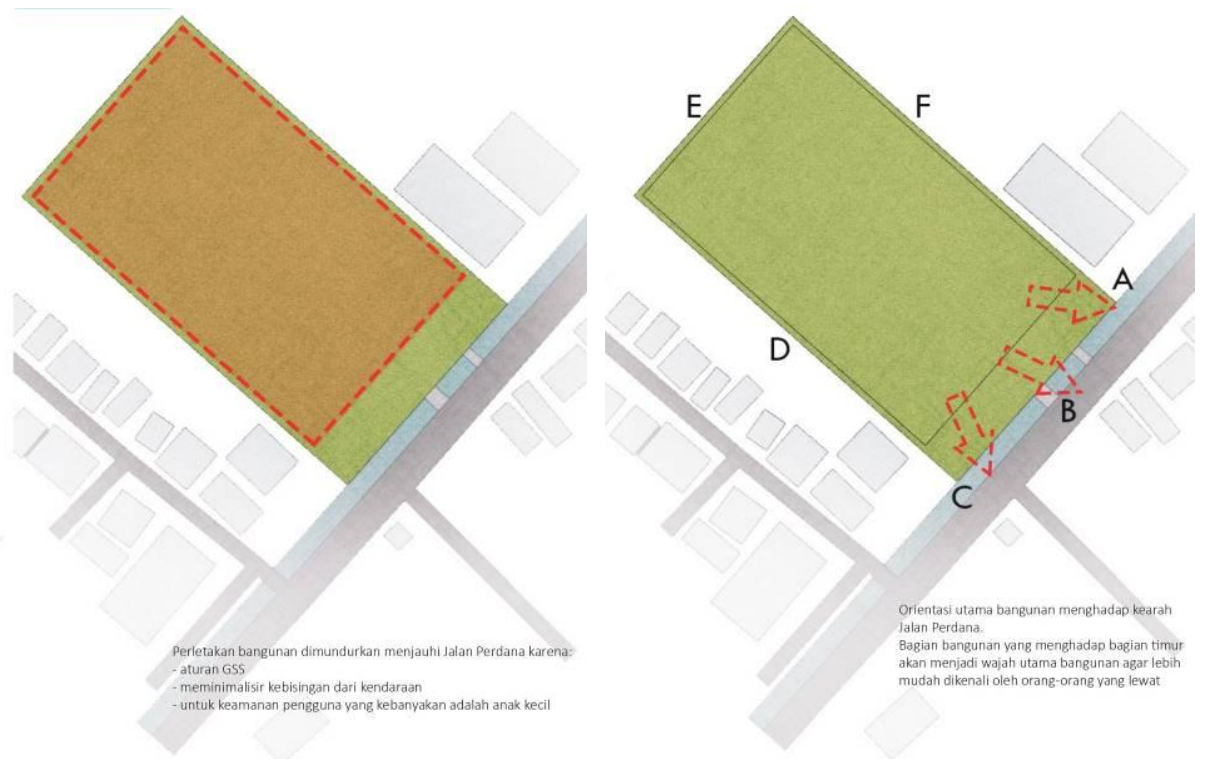

Gambar 4. Peletakan dan Orientasi

Sumber: Penulis, 2020

Zonasi mempertimbangkan aspek sirkulasi, visual, kebisingan dan iklim. Berdasarkan analisis tersebut tapak dibagi menjadi beberapa area yaitu 1) Area pendidikan berisi ruang sentra dan perpustakaan, 2) Area pengelola berisi ruang pengelola, 3) Area penunjang berisi ruang publik yang akan banyak digunakan oleh semua kategori pelaku, 4) Area servis berisi toilet dan ruang MEE, 5) Area terbuka berisi parkiran dan lapangan. Sirkulasi mempertimbangkan aspek eksisting tapak dan zonasi. Analisis dilakukan untuk mengatur pola sirkulasi pada tapak serta pencapaian dari jalan utama, dimana area masuk terletak di sisi kiri tapak dan area keluar di sisi kanan yang memiliki jembatan eksisting.

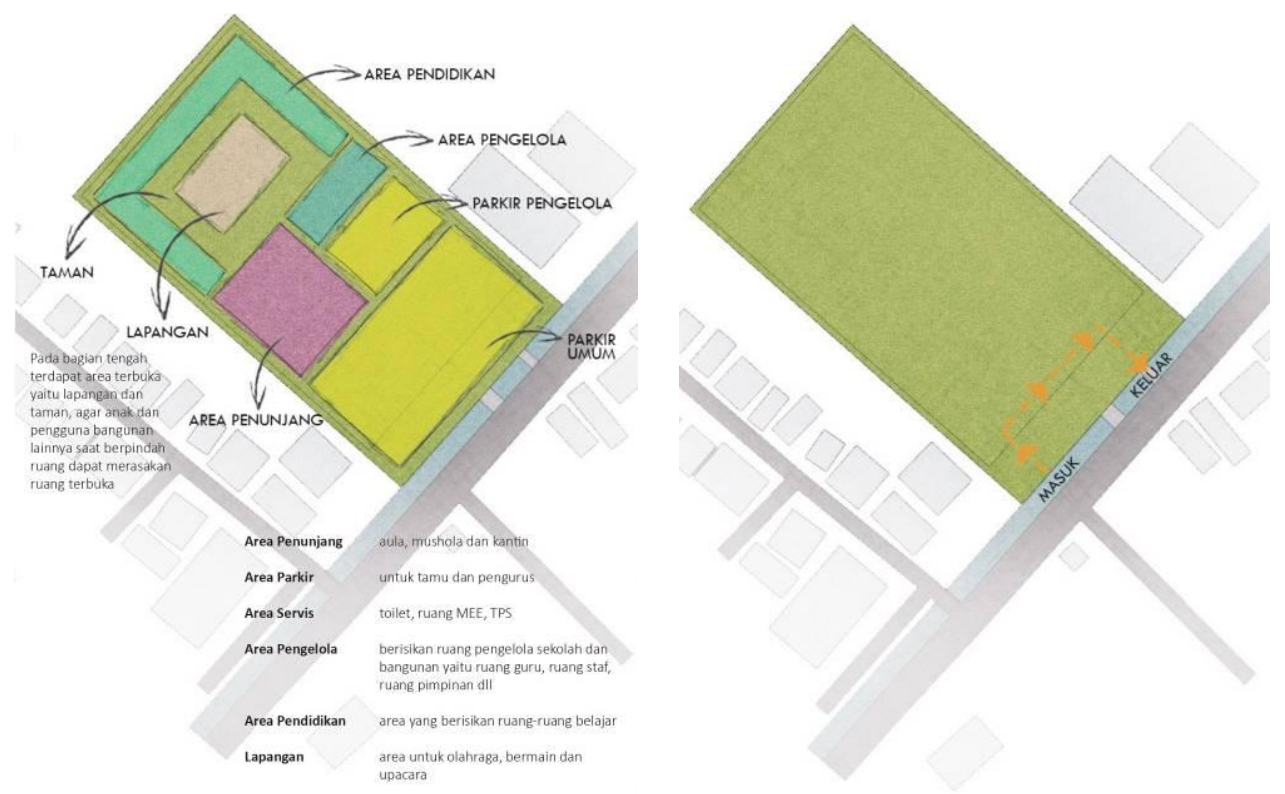

Gambar 5. Zonasi dan Sirkulasi

Sumber: Penulis, 2020

Vegetasi mempertimbangkan aspek iklim, sirkulasi dan zonasi. Tanaman yang digunakan dibagi menjadi 3 jenis yaitu sebagai peneduh, pengarah dan penghias. 


\section{Konsep Skematik Ruang}

Skematik ruang terbagi menjadi tata ruang dalam dan tata ruang luar. Tata ruang dalam bangunan dibagi menjadi area pendidikan, area pengelola, area penunjang dan area servis. Bangunan pada area penunjang terdiri dari 2 tingkat. Area pendidikan terbagi menjadi area untuk siswa kelas 13 dan kelas 4-6, berbentuk huruf $U$ dengan lapangan dan taman pada bagian tengah. Koridor pada area ini juga difungsikan sebagai area loker. Untuk mempermudah akses siswa menuju toilet, maka pada dua sisi ditempatkan toilet. Area pendidikan berisi ruang sentra (sentra bahasa, matematika, sains, sseni, main peran dan agama) dan perpustakaan.

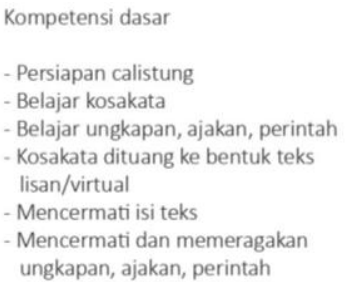

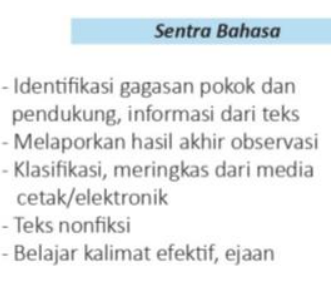
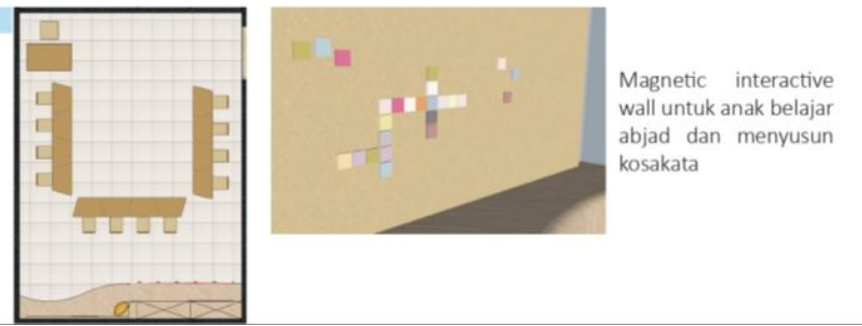

Kompetensi dasar

Mengenal anggota tubuh

Identifikasi benda di lingkungan sekitar, belajar sifat benda yang dapat berubah bentuk

- Mengenal bentuk energi serta manfaatnya (percobaan gerak benda yang mudah dan sulit bergerak, identifikasi penyebab benda bergerak dengan batere, pegas, dorongan tangan, magnet)

- Mengenal benda langit dan peristiwa alam

Mengenal bagian tubuh, pertumbuhan serta habitat makhluk hidup

- Energi di lingkungan sekitar dan perubahannya (percobaan sederhana, panas, listrik, cahaya dan bunyi)

Sentra Sains
- gaya listrik, otot, magnet
- pernafasan, pencernaan, peredaran
darah
- ekosistem
- kalor
- siklus air
- reproduksi makhluk hidup
- komponen listrik
- tata surya
- perubahan benda
- sifat benda (konduktor, isolator)

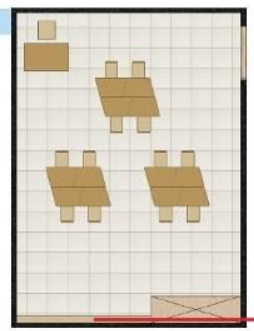

Magnetic interactive wall dengan latar gambar laut, daratan dan langit untuk anak menempelkan gambar makhluk hidup sesua habitatnya dan benda langit, serta untuk mempelajari gerak benda dengan magnet

\section{Kompetensi dasar}

Bermain peran tentang keberagaman individu, toleransi dalam hidup sehari-hari Memahami kedudukan dan peran anggota keluarga dan lingkungan bertetangga - Belajar aturan dan tata tertib di lingkungan sehari-hari

- Belajar rambu lalu lintas

\section{Sentra Main Peran}

Belajar rambu lalu lintas Identifikasi hak dan kewajiban sebagai warga

Belajar sejarah uang, main peran jual-beli - Main peran tentang kejadian bersejarah Mengetahui peran Indonesia terhadap era global (dampak positif negatif, kegiatan ekspor impor)

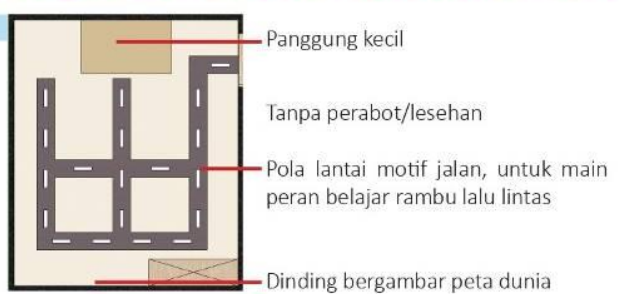

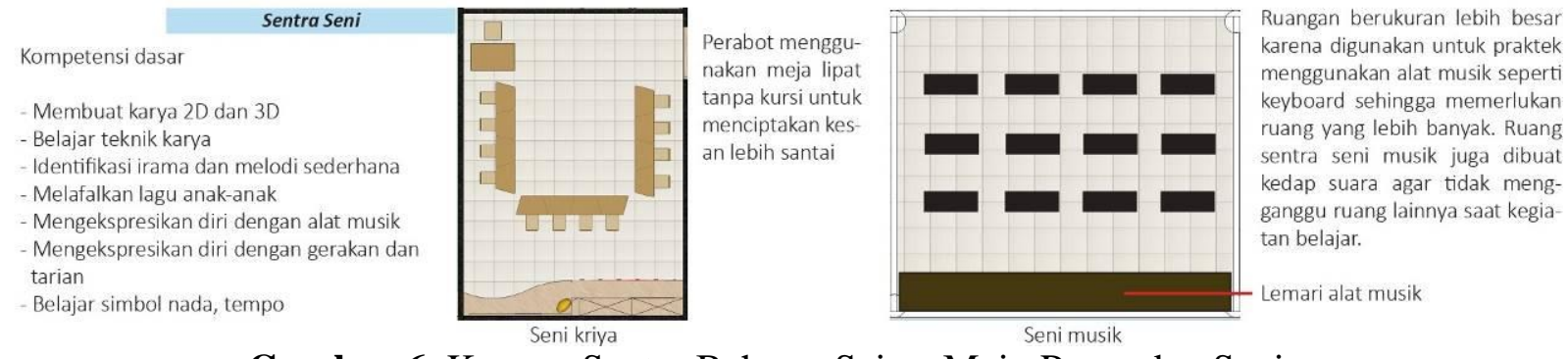

Gambar 6. Konsep Sentra Bahasa, Sains, Main Peran dan Seni

Sumber: Penulis, 2020 

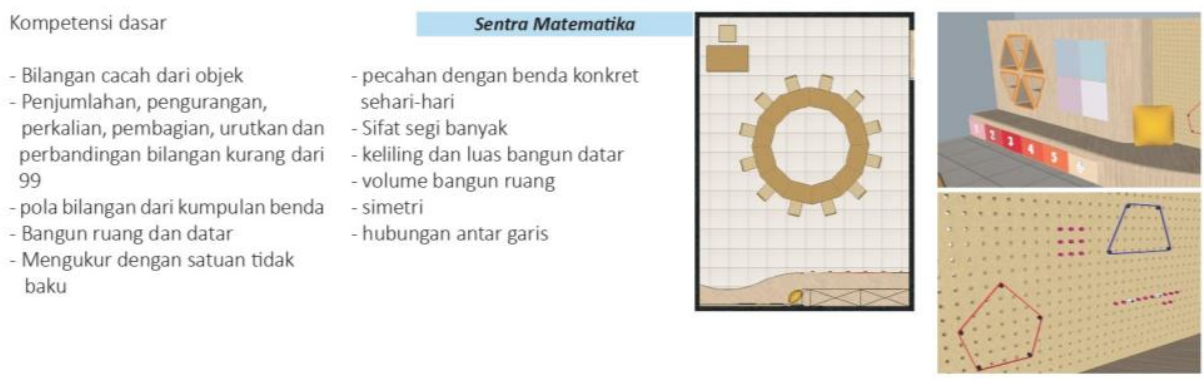

Lemari dan rak berbentuk bangun datar yang dipecah untuk an dari benda sekitar, dan angka pada laci

Gambar 7. Konsep Sentra Matematika

Sumber: Penulis, 2020

Tata ruang luar berisikan area taman, lapangan dan parkiran. Parkiran ditempatkan pada bagian depan dan terbagi menjadi area parkir pengelola yang diletakkan berdekatan dengan akses masuk menuju area pengelola pada bangunan untuk mempermudah sirkulasi dan area parkir tamu pada bagian paling depan.
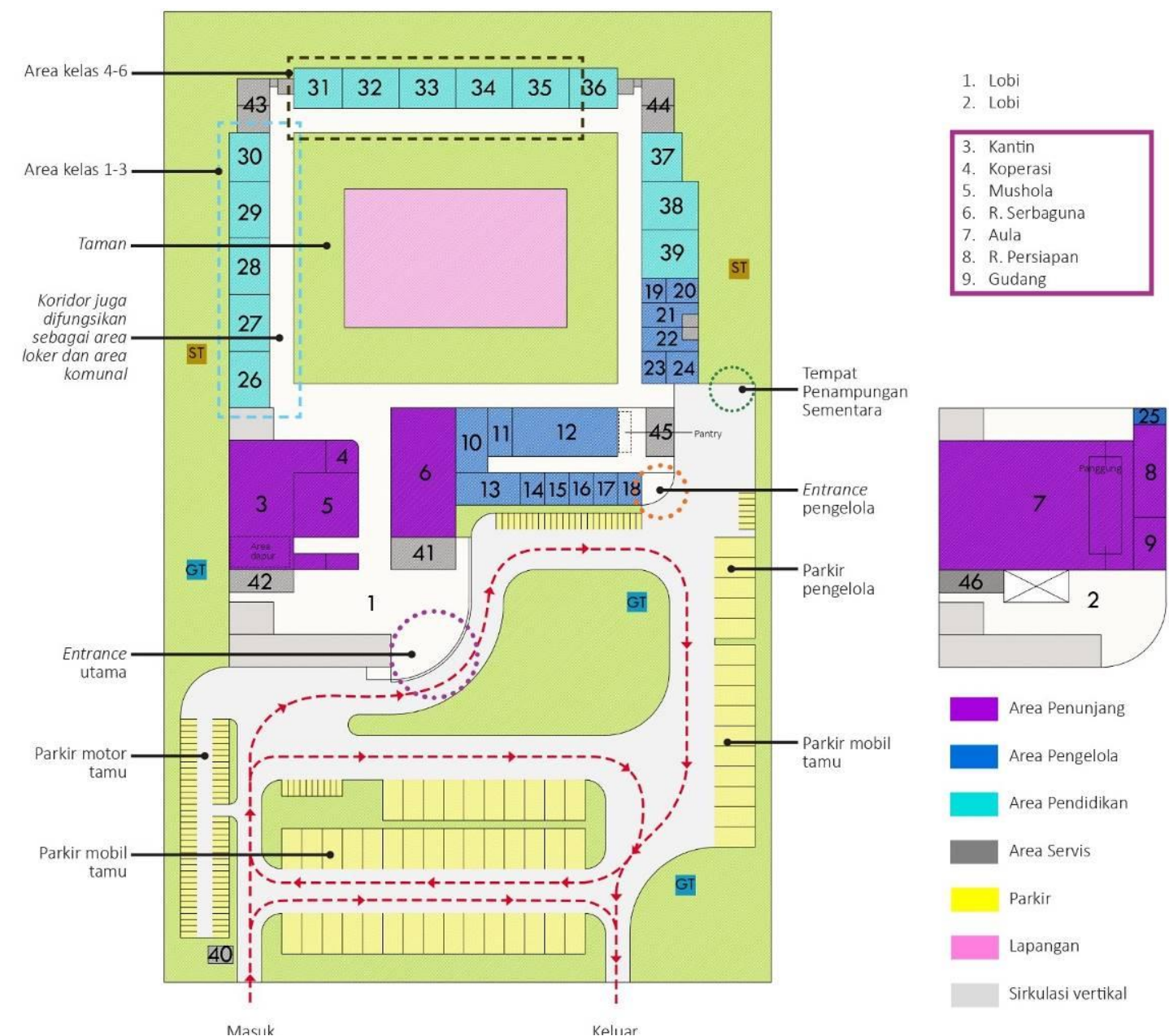

6. R. Waka

17. R. Waka

18. R. Waka

19. R. Staf perpus

20. R. Kepala perpus

21. UKS

22. R. Petugas

23. R. Konselor

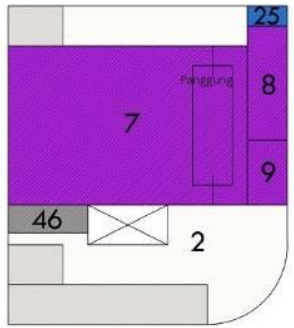

24. R. CCTV \& Sound

25. R. Kontrol aula

26. Sentra Bahasa

27. Sentra Mtk

28. Sentra Sains

29. Sentra Seni

30. Sentra Main Peran

31. Sentra Main Peran

32. Sentra Bahasa

33. Sentra Mtk

34. Sentra Sains

35. Sentra Seni

36. Sentra Agama

37. Sentra Agama

38. Ruang Musik

39. Perpustakaan

\begin{tabular}{|l|l|}
\hline Area Penunjang & \multicolumn{1}{|l|}{$\begin{array}{l}\text { 37. Sentra Agama } \\
\text { 38. Ruang Musik }\end{array}$} \\
\hline Area Pengelola & 39. Perpustakaan \\
\hline Area Pendidikan & $\begin{array}{l}\text { 40. Pos Satpam } \\
\text { 41. R. MEE }\end{array}$ \\
\hline Area Servis & 42. Toilet tamu \\
43. Toilet siswa \\
Parkir & 44. Toilet siswa \\
\hline 45. Toilet pengelola \\
46. Toilet tamu
\end{tabular}

Gambar 8. Tata Ruang Luar dan Dalam

Sumber: Penulis, 2020 


\section{Konsep Bentuk}

Analisis bentuk bangunan dipengaruhi oleh hasil analisis tapak serta fungsi dari bangunan sebagai bangunan pendidikan untuk anak usia 7-12 tahun. Massa bangunan terbagi menjadi 3 yaitu area pendidikan, area pengelola dan area penunjang. Untuk memenuhi kebutuhan ruang, area penunjang dibuat menjadi 2 lantai. Penjabaran lengkap dari analisis bentuk bisa dilihat pada ilustrasi di bawah ini.

1 Massa bangunan terbagi menjadi 3 area yaitu

1 area penunjang, pengelola dan pendidikan
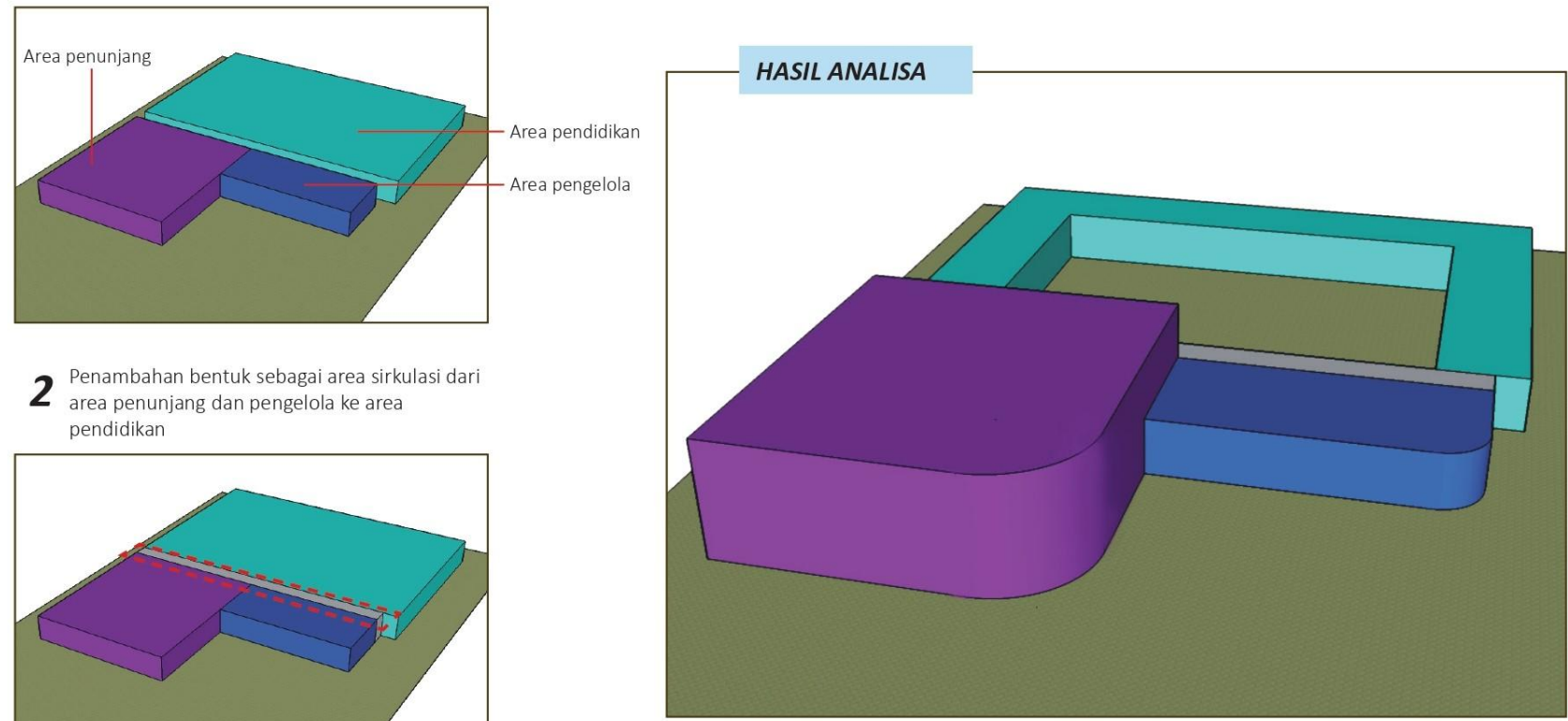

2 Penambahan bentuk sebagai area sirkulasi dari area penunjang dan pengelola ke area pendidikan

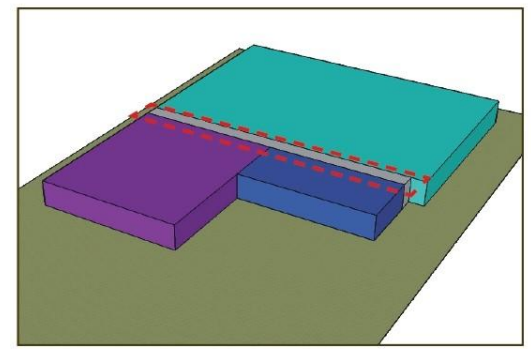

3 Penambahan bentuk secara vertikal pada area 3 penunjang untuk memenuhi kebutuhan ruang

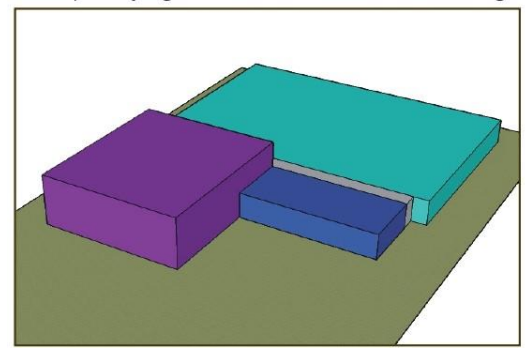

4 Pengurangan bentuk pada bagian tengah area pendidikan yang akan diletakkan lapangan

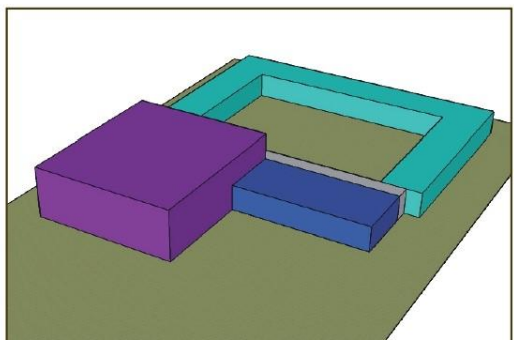

Gambar 9. Analisis Bentuk Sumber: Penulis, 2020
5 Pengurangan bentuk pada area penunjang dan 5 pengelola sebagai penegas entrance

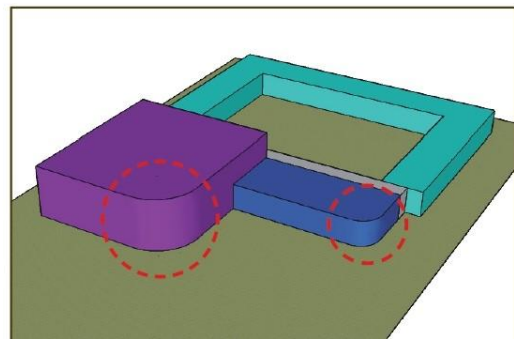

Hasil analisis tersebut disempurnakan pada tahap gubahan bentuk. Atap menggunakan atap miring untuk pertimbangan iklim. Bagian depan yang memiliki 2 tingkat diberi secondary skin berupa garis vertical untuk menutupi tampak atap dari depan serta memberi kesan tinggi. Dinding di sekeliling jendela dan bukaan pada void lantai 2 dibuat menonjol dengan warna cerah. 


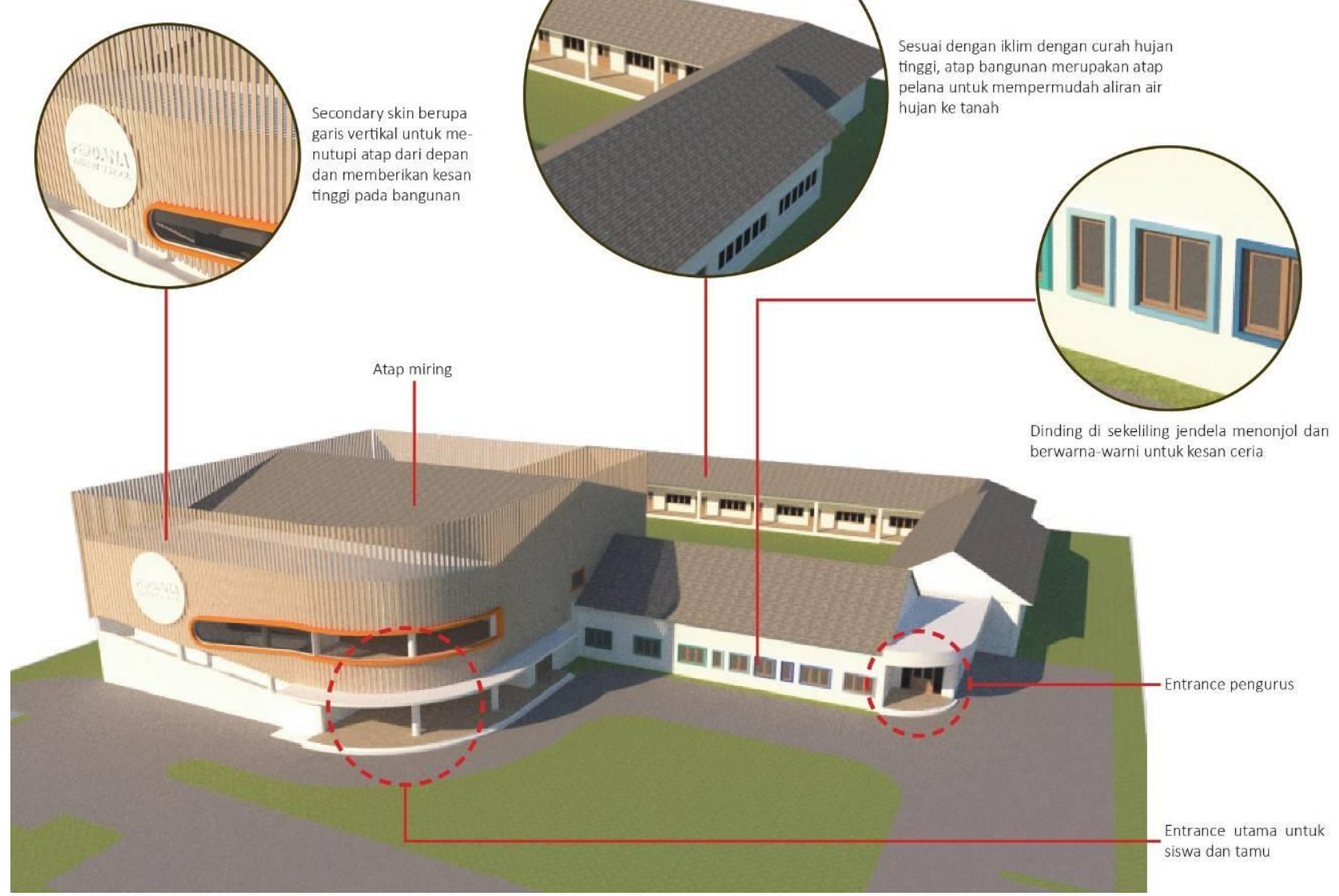

Gambar 10. Gubahan Bentuk

Sumber: Penulis, 2020

\section{Konsep Struktur}

Jenis tanah di lokasi terpilih adalah tanah gambut dengan daya dukung tanah yang rendah dengan kedalaman tanah keras sekitar 1-6 meter, sehingga dipilih sistem struktur yang ringan. Struktur bawah yaitu pondasi menggunakan pondasi tapak dengan mini pile. Struktur atas terdiri dari rangka bangunan dan atap. Bangunan menggunakan sistem rangka material beton bertulang, dinding menggunakan bata ringan sedangkan atap menggunakan rangka baja ringan.

\section{Konsep Utilitas}

Air bersih bersumber dari PDAM dengan sistem distribusi upfeed, dimana air akan ditampung pada ground tank dibawah tanah kemudian disalurkan dengan pompa menuju titik keluar outlet. Sistem limbah dibagi menjadi limbah padat yang akan ditampung di septic tank yang terletak pada sisi kiri dan kanan tapak sebelum dibuang ke riol kota sedangkan limbah cair dialirkan ke bak kontrol. Sistem tata udara menggunakan AC sentral untuk sistem yang lebih efisien dan fleksibel. Listrik bangunan bersumber dari PLN sebagai sumber utama dan genset untuk keadaan darurat. Telekomunikasi bangunan menggunakan ceiling speaker untuk bagian dalam bangunan dan horn speaker untuk bagian luar, serta CCTV berjenis PTZ (Pan, Tilt, Zoom) berupa Speed Dome PTZ dan PTZ IP Cam. Proteksi dari kebakaran dapat dilihat pada skema berikut. 


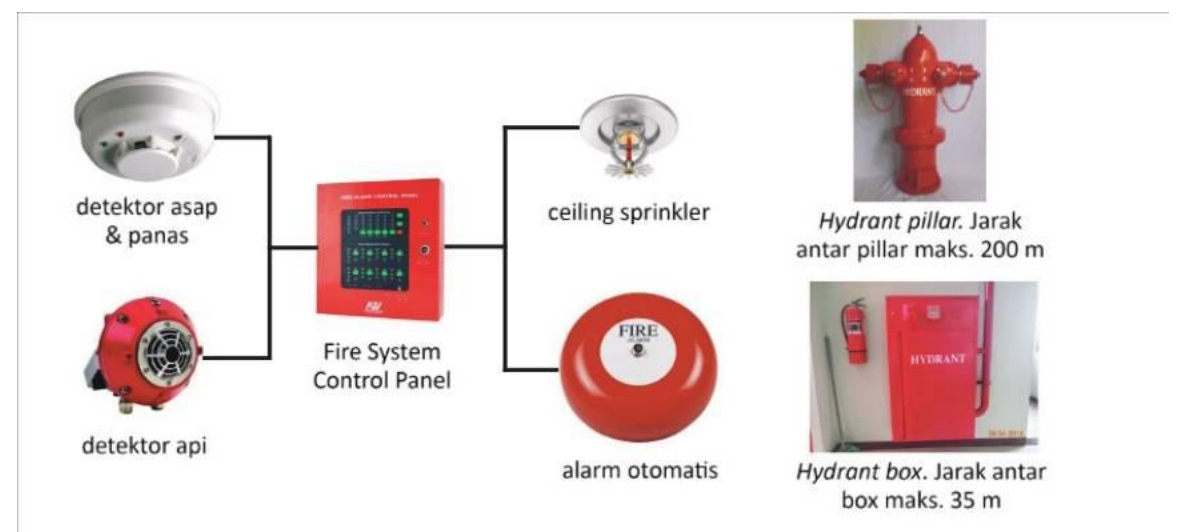

Gambar 11. Skema Proteksi Kebakaran

Sumber: Penulis, 2020

\section{Hasil Akhir Perancangan}

Gambar berikut ini ialah hasil akhir dari analisis dan konsep yang telah dijabarkan. Hasil perancangan yang akan ditampilkan berupa denah dan ilustrasi eksterior serta interior bangunan.

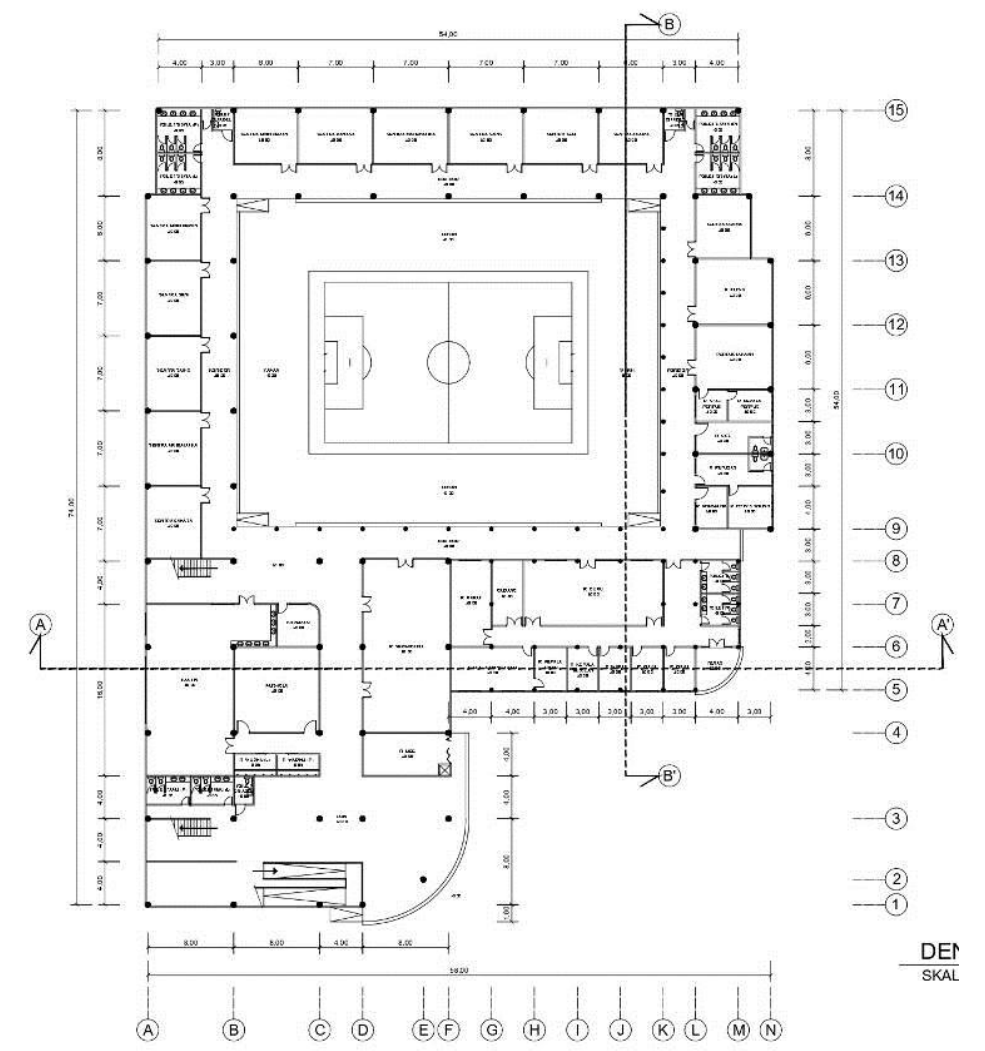

Gambar 12. Denah

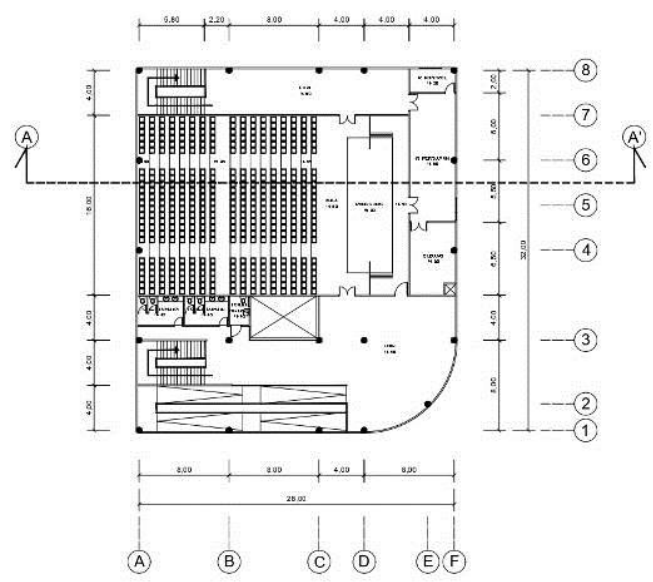

Sumber: Penulis, 2020

Bangunan didominasi warna putih dengan secondary skin motif kayu dan aksen warna jingga pada bagian bukaan di ruang lobi lantai 2. Jendela pada ruang-ruang pengelola di depan dibuat menonjol dan berwarna-warni sekelilingnya. Koridor pada area pendidikan yang berisi ruang-ruang sentra juga digunakan sebagai area loker. Area pintu masuk ke tiap ruang sentra dibuat lebih menonjol dengan penggunaan warna-warna cerah. 


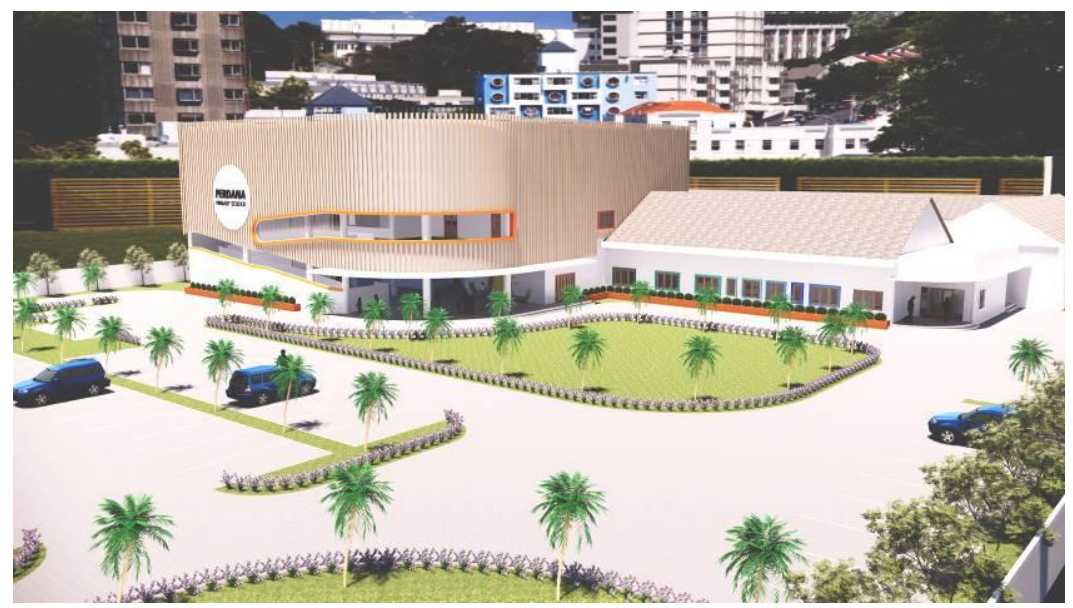

Gambar 13. Ilustrasi Eksterior

Sumber: Penulis, 2020

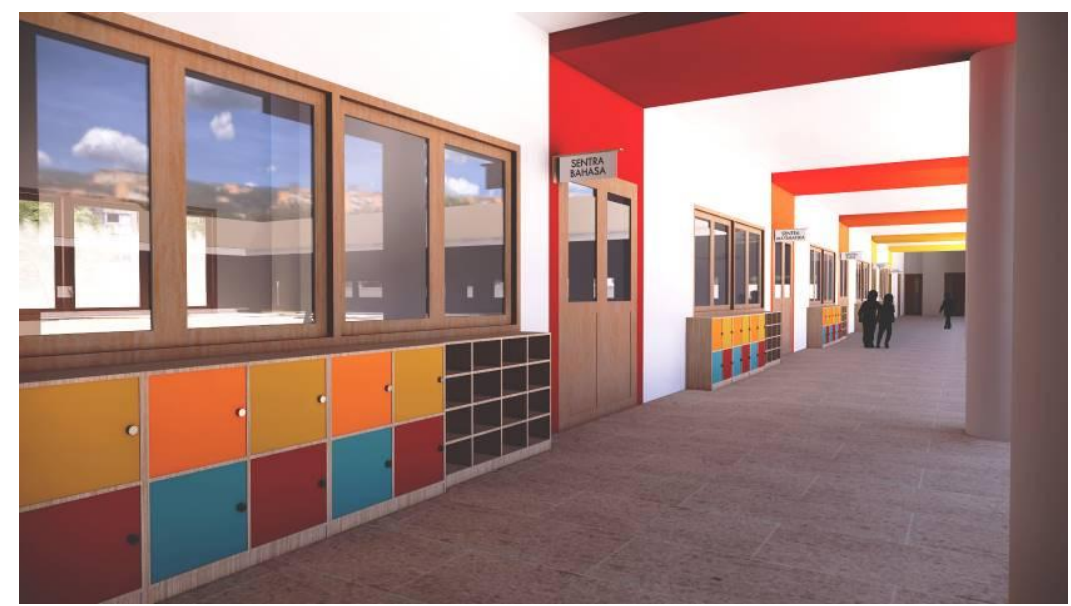

Gambar 14. Ilustrasi Eksterior Koridor

Sumber: Penulis, 2020

Bagian sekeliling lapangan adalah taman. Terdapat area duduk berbentuk setengah lingkaran dan walk path dengan kombinasi tekstur pada taman ini.

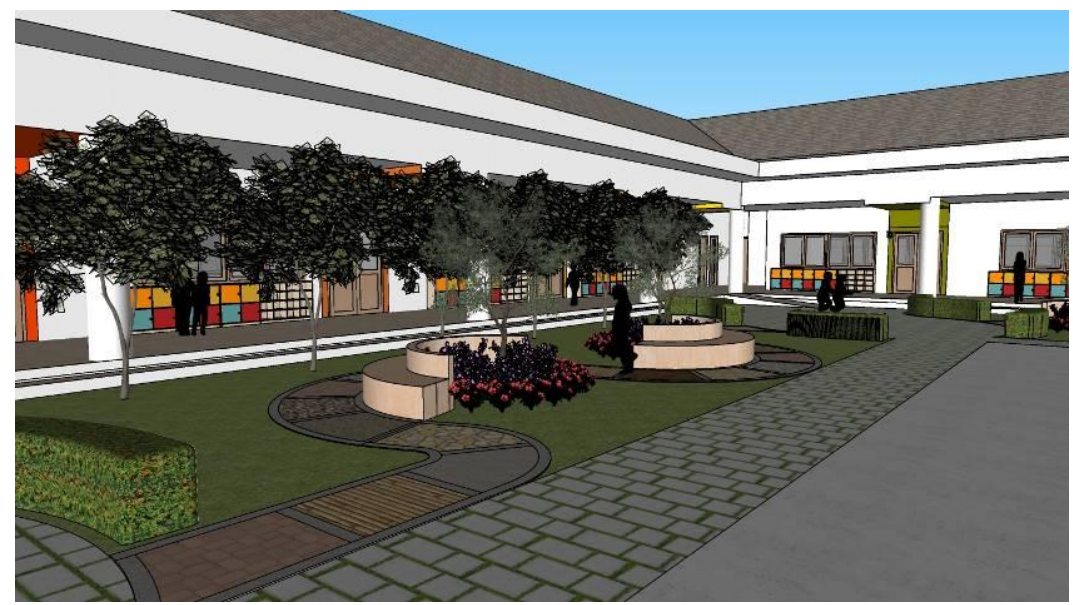

Gambar 15. Ilustrasi Taman

Sumber: Penulis, 2020 
Interior ruangan didominasi warna putih serupa dengan sentuhan warna cerah pada beberapa bagian. Pada ruang sentra terdapat lemari dan interactive wall di bagian belakang.

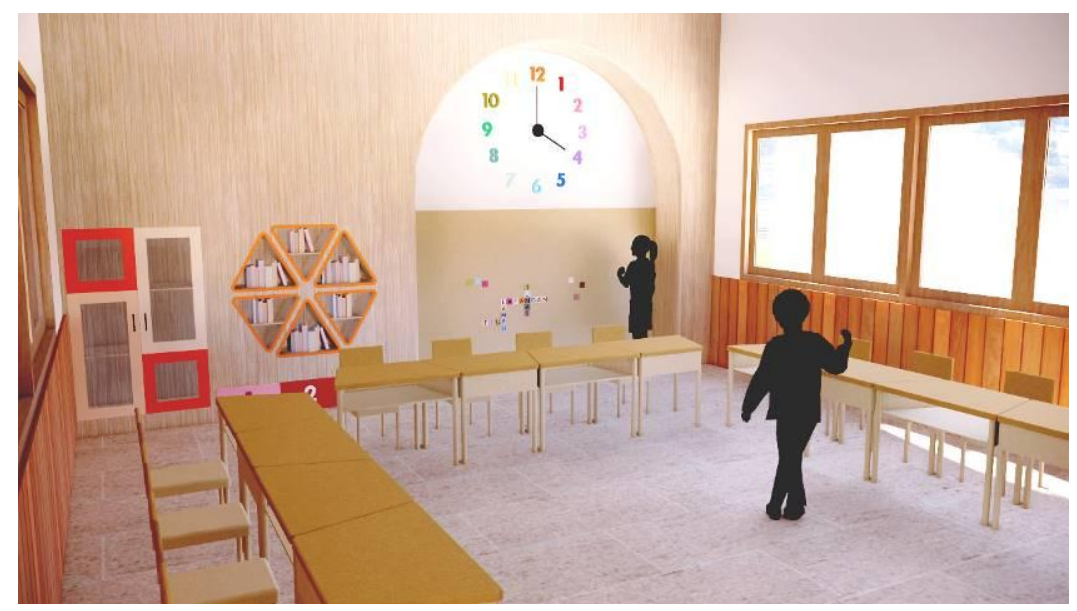

Gambar 16. Ilustrasi Interior Sentra Bahasa

Sumber: Penulis, 2020

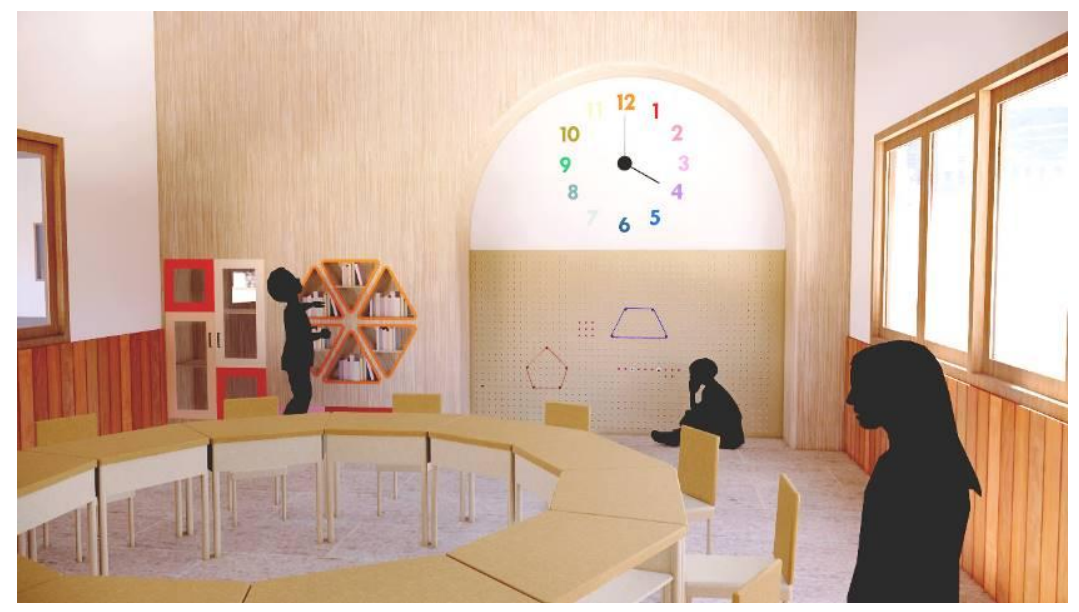

Gambar 17. Ilustrasi Interior Sentra Matematika Sumber: Penulis, 2020

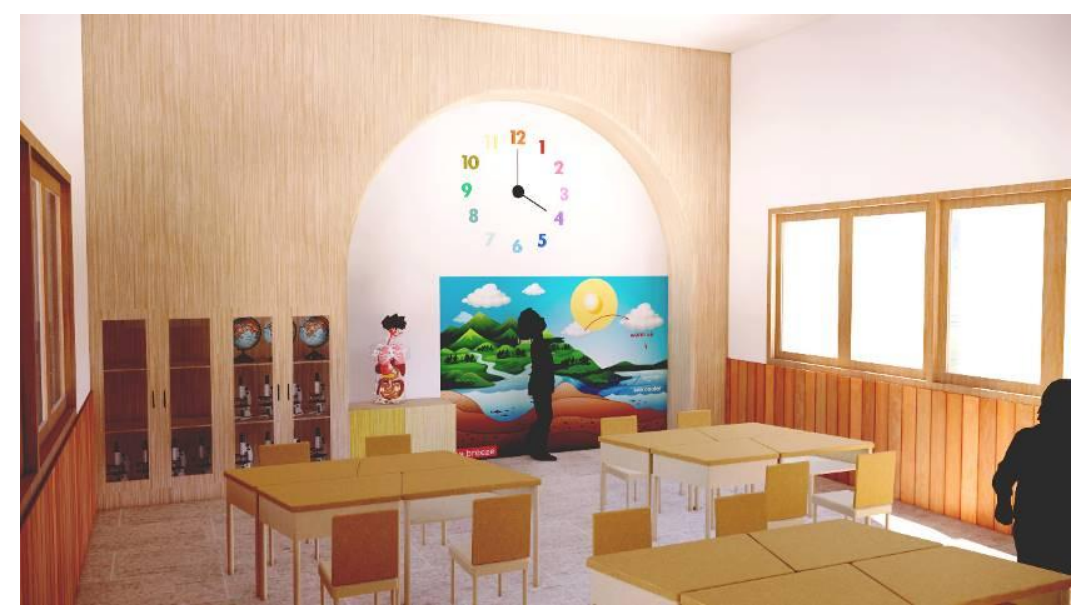

Gambar 18. Ilustrasi Interior Sentra Sains Sumber: Penulis, 2020 


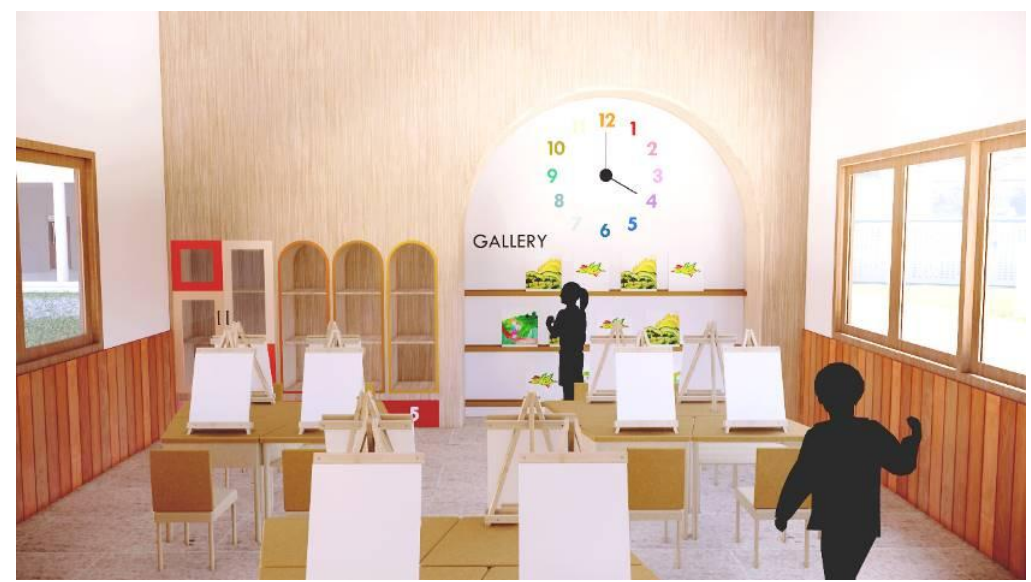

Gambar 19. Ilustrasi Interior Sentra Seni

Sumber: Penulis, 2020

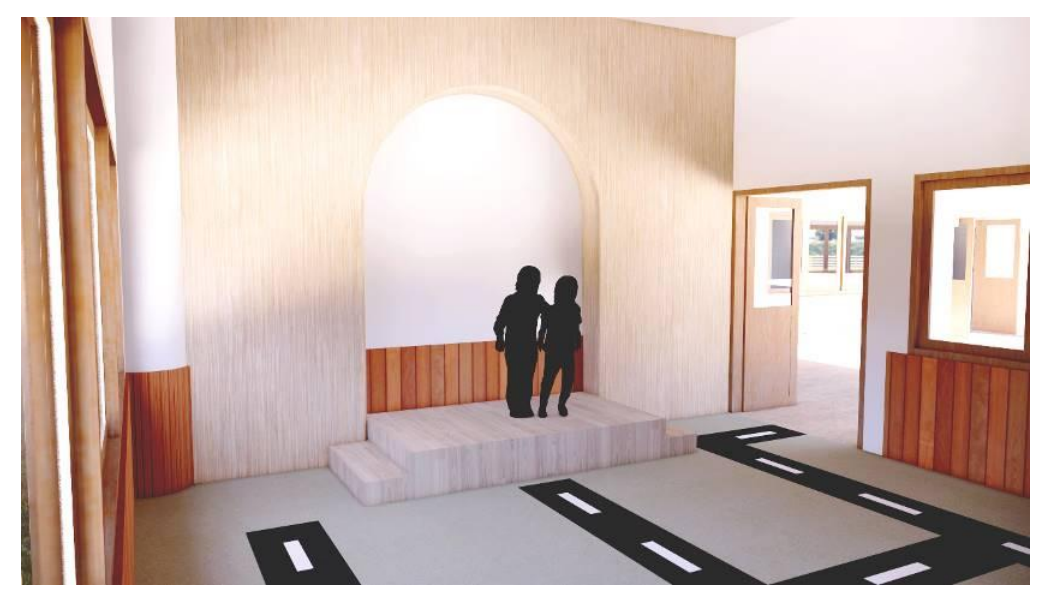

Gambar 20. Ilustrasi Interior Sentra Main Peran Sumber: Penulis, 2020

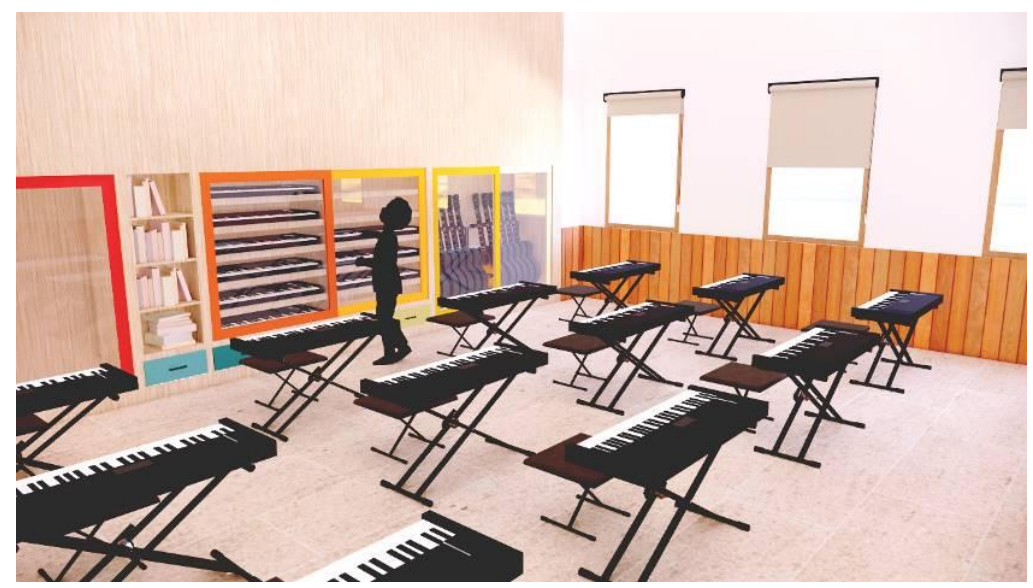

Gambar 21. Ilustrasi Interior Sentra Musik

Sumber: Penulis, 2020

\section{Kesimpulan}

Sekolah Dasar Berbasis Sentra di Kota Pontianak merupakan bangunan yang dirancang untuk memenuhi kebutuhan belajar anak usia sekolah dasar berdasarkan metode pembelajaran BCCT atau metode Sentra dan Lingkaran. Perancangan dilakukan dengan metode pembelajaran BCCT karena 
metode ini dinilai sesuai untuk mendukung pertumbuhan dan perkembangan anak pada usia sekolah dasar, dengan sistem moving class dimana tiap ruang kelas sentra dirancang agar sesuai dengan kebutuhan anak dan apa yang akan dipelajari pada sentra tersebut, serta peletakan ruang kelas yang dikelompokkan menjadi untuk siswa tingkat 1-3 dan 4-6 agar mempermudah sirkulasi saat perpindahan kelas.

\section{Ucapan Terima Kasih}

Terima kasih kepada Bapak M. Nurhamsyah, S.T., M.Sc. selaku ketua Jurusan Arsitektur sekaligus dosen pembimbing utama dan Ibu Lestari, S.T., M.T. selaku dosen pembimbing kedua.

\section{Daftar Acuan}

Ahmadi, A., \& Uhbiyati, N. (2001). Interaksi Belajar Mengajar. Bandung, Indonesia: Remaja Karya

Center for Citizenship Education Foundation. (2016). Physical and Architectural Learning Environments. Retrieved from http://www.eduspaces.eu/p/guidebooks.html

Direktorat Pembinaan Pendidikan Anak Usia Dini. (2011). Pedoman Teknis Penyelenggaraan Kelompok Bermain. Retrieved from http://paud.kemdikbud.go.id

Hanafi, M. Z. (2014). Implementasi Metode Sentra Dalam Pengembangan Kecerdasan Majemuk Anak Usia Dini. Jakarta, Indonesia: Deepublish

Kementerian Pemberdayaan Perempuan dan Perlindungan Anak RI. (2015). Panduan Sekolah Ramah Anak. Retrieved from https://sekolahramahanak.files.wordpress.com

Kementerian Pendidikan Nasional Republik Indonesia. (2007). Peraturan Menteri Pendidikan Nasional Republik Indonesia Nomor 24 Tahun 2007 tentang Standar Sarana dan Prasarana untuk Sekolah Dasar/Madrasah Ibtidaiyah (SD/MI), Sekolah Menengah Pertama/Madrasah Tsanawiyah (SMP/MTS), dan Sekolah Menengah Atas/Madrasah Aliyah (SMA/MA). Retrieved from http://repositori.kemdikbud.go.id/18715/1/Permendiknas-No.24-tahun-2007.pdf

National Association for the Education of Young Children. (1992). Developmentally Appropriate Practice In Early Childhood Programs, Serving Children from Birth to Age 8. Washington DC, United States: NAEYC

Noorlaila, I. (2010). Panduan Lengkap Mengajar PAUD. Yogyakarta, Indonesia: Pinus Book Publisher

Nuraini, C. (2010). Metode Perancangan Arsitektur. Bandung, Indonesia: Karya Putra Darwanti

Nurihsan, J. (2007). Buku Materi Pokok Perkembangan Peserta Didik. Bandung, Indonesia: UPI

Purwoko, A. (2001). Panduan Penelitian PTK. Semarang, Indonesia: Unnes Press

Sumantri, M. S. (2005). Pengembangan Keterampilan Motorik Anak Usia Dini. Jakarta, Indonesia: Dinas Pendidikan

Supriyanto, D. (2014). Meningkatkan Proses Pembelajaran melalui Moving Class. Jurnal Program Studi PGMI, 1, 1-14 